Ilmenau University of Technology

Institute of Economics

Ilmenau Economics Discussion Papers, Vol. 19, No. 85

The Competition Economics of Financial Fair Play

Oliver Budzinski

März 2014

Institute of Economics

Ehrenbergstraße 29

Ernst-Abbe-Zentrum

D-98 684 Ilmenau

Phone 03677/69-4030/-4032

Fax 03677/69-4203

http://www.wirtschaft.tu-ilmenau.de

ISSN 0949-3859 


\title{
The Competition Economics of Financial Fair Play
}

\author{
Oliver Budzinski ${ }^{\#}$ \\ *** This paper will be published in: O. Budzinski \& A. Feddersen (eds.), Contempo- \\ rary Research in Sports Economics, Frankfurt a.M.: Lang, May/June 2014 ***
}

\begin{abstract}
This paper provides an economic analysis of the competition effects of UEFA's financial fair play regulations. It concludes that the restrictive effects of the break-even rule cannot be justified by a legitimate objective defense (according to European competition policy) because significant financial problems due to overinvestment are not inherent to European football.
\end{abstract}

Keywords: financial fair play, sports economics, competition economics, European competition policy, football, soccer, overinvestment, rat race

\section{Introduction}

Professional sports - and European-style football ${ }^{1}$ in particular - is a serious commercial business with considerable turnovers and revenues. As a consequence, powerful market participants experience incentives to reap supracompetitive rents by restricting the beneficial forces of competition at the expense of customers or suppliers. At first sight, however, such powerful or dominant players do not seem to exist in professional sports. In contrast to ordinary goods markets, professional sports requires the existence of a sufficient number of competitors in order to produce the product at all (Rottenberg 1956; Neale 1964): a monopoly football club would obviously not be able to provide a marketable good. Thus, there is typically no worry of single-club dominance in this sense. However, sports competition also requires the definition, implementation and enforcement of sporting rules. This is typically the role of sports associations who govern and regulate the sports competition. Sports associations usually are private companies (sometimes non-for-profit companies) and, in football, membership associations with the members being lower-level sports associations and, at the bottom of the pyramid, the clubs who provide football teams on all levels. For instance, the UEFA (Union of European Football Associations) consists of national

\footnotetext{
\# Prof. Dr. Oliver Budzinski, Professor of Economic Theory, Institute of Economics, Ilmenau University of Technology, Email: oliver.budzinski@tu-ilmenau.de. I thank Ina Fredersdorf, Nadine Neute and Stefanie Riemer for valuable editorial assistance.

${ }^{1}$ Throughout this paper, the term football will refer to European-style football (sometimes also labeled soccer) - and not to American football.
} 
football associations as members such as the DFB (Deutscher Fußball-Bund; Germany), the FA (The Football Association; England) or the RFEF (Real Federación Española de Fútbol; Spain). The national associations then consist of regional associations and the regional associations have all the clubs playing football within their region as members - including professional clubs as well as grassroots clubs. Along this pyramidal structure, all these football associations enjoy a monopoly position within their region. The resulting market power is rather modest on the bottom levels of the pyramid since being a member of the higher level association implies the duty to stay in line with the higher level associations while, at the same time, the influence on the higher level association is often rather limited due to the large number of voting members. Furthermore, the lowest level associations usually do not govern a professional league; instead, they are dealing with amateur and grassroots leagues and competitions. The market power on the top level of the pyramid, however, is significant since this is the level where the most valuable competitions take place (the UEFA Champions League and the UEFA Europa League) and a large number of member associations imply substantial scope for independent action. While it may be debatable how independent from the national associations UEFA can act, it appears to be rather obvious that the influence of the clubs participating in UEFA's competitions is rather indirect - either through the chain of associations along the pyramidal structure or through lobbyism. ${ }^{2}$

In summary, it does not seem to be far-stretched to ascribe a significantly powerful position to UEFA. In economic terms, UEFA is a market-internal regulatory agency enjoying a monopoly position. Now, how are the activities of a sports association relevant to the professional sports market, i.e. to the commercial side of sports? Firstly, UEFA (like most associations governing commercialized sports competitions) engages not only in setting and enforcing sporting rules, but also in commercial activities, namely the bundling and sale of broadcasting rights for the UEFA competitions as well as the marketing of the brands of these competitions. Secondly, the setting and enforcing of sporting rules itself entails a business element that is difficult to disentangle. Sporting rules may well be shaped with the purpose of increasing the attractiveness of sports and, thus, turnovers and revenues. And, sporting rules may well be shaped with the effect of reducing competition intensity in order to reap supracompetitive rents from customers or suppliers. ${ }^{3}$ Therefore, rule-making activities by UEFA constitute a commercial strategy by a dominant entity - and, as such, scrutiny regarding the effects on competition is justified.

Consequently, the so-called financial fair play regulations (FFP) implemented by UEFA may raise competition concerns since they regulate the investment behavior of clubs

\footnotetext{
${ }^{2}$ Budzinski \& Szymanski (2014) provide a discussion whether UEFA may be viewed as a horizontal cartel of football clubs or an independent player with a monopoly position in the market for competition organizing services, representing a bottleneck along the vertical supply chain of professional football.

${ }^{3}$ Consequently, the European Court of Justice ruled in its landmark Meca-Medina case that sporting rules are subject to competition policy and must comply with competition law. See Case C-519/04P, Meca Medina v. Commission, ECR 2006, I-6991.
} 
participating in UEFA club competitions - an intervention that appears to be potentially restrictive from the outset on. And, indeed, in 2013, the Belgium player agent Daniel Striani launched a complaint with the European Commission as well as a proceeding at the European Court of Justice against FFP (inter alia) on competition law grounds. ${ }^{4}$ According to the sports-specific competition policy practices of the European Commission (following the Meca-Medina judgment of the European Court of Justice), rules enacted by sports associations do not violate European competition law if

(a) they pursue legitimate objectives (legitimacy),

(b) their restrictive effects are inherent to these objectives (inherence), and

(c) proportional to the benefits (proportionality). ${ }^{5}$

In this paper, I argue from a competition economics perspective that UEFA's financial fair play regulations in its current shape violate the principles of inherence and proportionality and, thus, deserve a critical review by competition policy authorities. After summarizing the main features as well as outlining the possible anticompetitive effects of FFP (section 2), I review the three principles legitimacy, inherence and proportionality against the background of economic theory (section 3). Eventually, I reflect upon the results including possible alternatives (section 4). Sticking to an economic analysis, neither do I dwell upon legal questions and theories, nor do I predict outcomes of legal procedures. Instead, I provide hints about an economic assessment of FFP within the current competition policy framework in Europe.

\section{Possible Restrictive Effects of Financial Fair Play}

The UEFA $(2012,2014)$ introduced FFP in September 2009 as a part of revised licensing regulations, coming into full force with the $2013 / 2014$ season. ${ }^{6}$ Every club that wants to enter one of UEFA club competitions (UEFA Champions League and UEFA Europa League) must obtain an UEFA license (next to the sporting qualification via the national leagues) and, thus, comply with the financial fair play regulations.

The FFP regulations consist, in substance, of two rules:

- the no overdue payables rule: overdue payables are understood to be all outstanding payments (towards employees, social and tax authorities or other clubs) that have not been paid by the contractually agreed deadline, and

\footnotetext{
4 See http://www.financialfairplay.co.uk/latest-news/legal-challenge-to-uefa-ffp-rules-by-bosmanlawyer and http://www.financialfairplay.co.uk/latest-news/further-legal-challenge-to-ffp-by-strianiand-dupont (both accessed 2014-02-15, 16.38)

${ }^{5}$ See representing the view of the European Commission Kienapfel \& Stein (2007), providing a legal
analysis Weatherill (2006), and providing an economic analysis Budzinski (2012).

${ }^{6}$ See for economic-based analyses of FFP Vöpel (2011), Madden (2012), Müller et al. (2012), Peeters \& Szymanski (2012, 2014a, 2014b), Preuss et al. (2012), Sass (2012), Franck (2013), Hamil (2014), Maxcy (2014), Szymanski (2014) as well as Lindholm (2010) and Long (2012) for legal sciences-based analyses and Könecke \& Schubert (2014) for a social sciences-based analysis.
} 
- the break-even rule: relevant expenses must be paid out of relevant income or, in other words, relevant expenses must not exceed relevant income (see table 1); an aggregate deviation of up to $€ 5$ million (over three financial years) is acceptable.

Violations of these rules trigger a series of sanctions, ranging from reprimands to the exclusion of the non-complying club from the European club competitions.

Table 1: The Break-Even Rule

Source: own compilation from UEFA (2012: 72-82)

\begin{tabular}{|c|c|c|}
\hline RELEVANT INCOME & & RELEVANT EXPENSES \\
\hline $\begin{array}{l}\text { - } \quad \text { gate revenues } \\
\text { revenues from sponsorship } \\
\text { and advertising } \\
\text { revenues from broadcasting } \\
\text { rights } \\
\text { commercial activities reve- } \\
\text { nues (merchandising, food } \\
\text { and beverages sales, confer- } \\
\text { encing, lotteries, etc.) } \\
\text { other operating income (in- } \\
\text { cluding non-football income } \\
\text { related to the club) } \\
\text { finance income (interest reve- } \\
\text { nue) }\end{array}$ & $\geq$ & $\begin{array}{l}\text { - } \quad \text { costs of sales and materials } \\
\text { - } \quad \text { wages and salaries (including } \\
\text { related expenses such as social } \\
\text { security contributions or medi- } \\
\text { cal care) } \\
\text { - } \quad \text { other operating expenses (e.g. } \\
\text { match expenses, administra- } \\
\text { tion and overhead expenses) } \\
\text { - } \quad \text { finance costs and dividends }\end{array}$ \\
\hline NON-RELEVANT INCOME & & NON-RELEVANT EXPENSES \\
\hline $\begin{array}{l}\text { - } \\
\text { income transactions above } \\
\text { - } \quad \text { doir value } \\
\text { of debt by a third person } \\
\text { - income from non-football op- } \\
\text { erations not related to the } \\
\text { club } \\
\text { income from non-monetary } \\
\text { credits (e.g. revaluations of } \\
\text { assets and inventories) }\end{array}$ & & $\begin{array}{l}\text { - } \quad \text { expense transactions below } \\
\text { fair value } \\
\text { - } \quad \text { youth development } \\
\text { - } \quad \text { community development ac- } \\
\text { tivities (e.g. promoting partici- } \\
\text { pation in sports or advancing } \\
\text { social development in educa- } \\
\text { tion, health, amateur sports, } \\
\text { etc.) } \\
\text { - non-monetary debits and } \\
\text { charges } \\
\text { finance costs of tangible fixed } \\
\text { assets } \\
\text { non-football operations not } \\
\text { related to the club } \\
\text { income taxes }\end{array}$ \\
\hline
\end{tabular}

\footnotetext{
7 The UEFA determines the fair value of relevant transactions according to conventional business practices. If the estimated fair value differs from the recorded value, then an adjustment must be made. In the case of income, however, no upward adjustment is possible, in the case of expenses, no downward adjustment is possible (UEFA 2012: 75, 78).
} 
While the no overdue payables rule relates to issues of payment behavior and solvency, the break-even rule interferes with the investment behavior of the clubs. It effectively caps the investment of the competitors on the market for match playing services (the clubs) because it restricts the maximum expenses for the competition team (= relevant expenses) to the volume of the defined relevant income. As such, it represents a relative budget cap. This has two important implications:

1. The cap is uneven among competitors in the sense that clubs with higher relevant income are allowed to spend more than clubs with lower relevant income. In this sense, FFP represents a discriminatory cap.

2. The definition of relevant income excludes some types of sources for financing investment into the competition team. Notably, financial injections by socalled benefactors (sometimes also labeled sugar daddies; e.g. Lang et al. 2011; Franck \& Lang 2012; Franck 2013) do not present relevant income and, thus, cannot serve to break even expenses. Somewhat simplifying, the concept of relevant income requires the clubs to live on their football related (earned) incomes and revenues. Note, however, that for a transitional period, injections that increase the equity of a club (injections by shareholders) increase the acceptable deviation between relevant incomes and relevant expenses. The acceptable volume is decreasing over time with the goal of diminishing it (UEFA 2012: 36). ${ }^{8}$

The no overdue payables rule does not appear to cause considerable restrictive effects, whereas the break-even rule comes along with several anticompetitive concerns, namely (i) the salary reduction effect, (ii) the incumbent protection effect, (iii) the consolidation effect, and (iv) the investment security effect.

The salary reduction effect refers to the effects of the break-even rule on the market for talent, i.e. the players market, as well as on the related market for consulting services for players (the players' agents market). Expenses on player salaries as well as on transfer activities represent the dominant part of the relevant expenses of professional football clubs. If the break-even rule caps expenses due to the limitation to relevant income as a source of financing expenses, then it is very likely that a downward trend in players' salaries as well as in transfer payments will result. ${ }^{9}$ The deflatory effect on the level of players' salaries will cause an accompanying deflatory effect on the revenues of players' agents. In summary, the investment level reduction induced by FFP comes at the expense of the earning possibilities of players and players'

\footnotetext{
${ }^{8}$ The starting volume is $€ 45$ million and is reduced to $€ 30$ million until 2018. After that "a lower amount as decided in due course by the UEFA Executive Committee" (UEFA 2012: 36) will come into force.

${ }^{9}$ Indeed, economic simulation models provide support for the dampening effect on player salaries (Peters \& Szymanski 2014a, 2014b).
} 
agents. Thus, rents are shifted away from these groups to the clubs and/or UEFA, which represents a restrictive effect towards upstream suppliers. ${ }^{10}$

The incumbent protection effect refers to the above explained implications of the relative character of the cap. Basically, the break-even rule implies that clubs need to adjust their investment (into talent) to the level of their revenues. If a club enjoys high revenues, then it is able to spend accordingly. If a club suffers from low revenues, then it needs to keep its expenses on a low level as well. This means that clubs who enjoy high revenues right now can maintain their competitive advantage by high investments. However, clubs who do not enjoy high revenues right now cannot freely invest into becoming more competitive. Instead, FFP forces them to maintain their lower competitive level by capping their investments. In other words, the breakeven rule frustrates catching-up investments. This favors the incumbents on the top level of European football who enjoy high revenues because of recent success and valuable brands (because of more historical success). It disadvantages clubs who are not on that top level yet but who want to challenge the incumbents. In summary, FFP cements the market structure on the top level of European football (Vöpel 2011; Drut \& Raballand 2012; Sass 2012; Szymanski 2014) and protects the incumbents from new challenges by upward-pressuring upstarts, newcomers and maverick competitors. Thus, the competition for participating in (and entering) the top leagues may be significantly impeded by FFP (creating a barrier to entry). While this restrictive effect is a general one, it may be particularly directed towards upstarts that are financed by wealthy private persons (e.g. FC Chelsea, Manchester City, Paris St. Germain) or by company ownership (e.g. the engagement of Red Bull) who are increasingly challenging the established big clubs. Restricting these money injections may be particularly welfare-reducing (Madden 2012).

The related consolidation effect refers to a decreasing volatility of changes in competitive advantages and disadvantages. FFP may be viewed to be an agreement that clubs seeking to improve themselves must do so in a slow and measured fashion that is less likely to create losses but, by the same token, also is less likely to create upsets. As a consequence, changes in competitiveness happen slower than fans want - and would be willing to pay for if the investments were successful (see Coates et al. 2014 on the importance of upsets for consumer welfare in professional sports).

Eventually, the investment security effect points to an anticompetitive exclusion of entrepreneurial risk. FFP via its break-even rule is likely to lessen the risk of bad investments (e.g. into talent) since both the volume of investment and the magnitude of competitiveness consequences are deflated.

In total, FFP - or the break-even rule, in particular - may lessen competition intensity at the expense of the fans. Negative effects on consumer welfare may arise through two channels. Firstly, the deflating effect on salaries and transfer payments is likely to lead to a reduction of the level of talent quality. Top European players looking for

\footnotetext{
${ }^{10}$ See the reasoning of Dupont (2013) who, as the lawyer of Striani, is advocating the antitrust complaint against FFP. He views FFP to be the action of a cartel among the clubs (transmitted via the UEFA as an association of clubs) in order to exploit the (upstream) players' and players' agent markets.
} 
their best earning options may decide to leave the European market and top foreign talent may be more reluctant to enter the European market. Since it is part of fans' welfare to witness outstanding talent (economics of superstars) a reduction of talent quality ceteris paribus goes along with a reduction in consumer welfare - in particular if the talent reduction is not associated with a price reduction ${ }^{11}$. Secondly, the lower competition intensity due to the incumbent protection effect and the consolidation effect may lead to decreasing competitive efforts by the clubs which harms the performance level. Being protected against new challengers combined with an ossifying effect on the relative competitiveness of the participants enables both the UEFA and the incumbent competitors to extract supracompetitive rents at the expense of fans ${ }^{12}$, in particular, if there are no close substitutes to premier level European football.

\section{Are the Restrictive Effects Defendable?}

The anticompetitive stories outlined in the preceding section show that FFP causes restrictive effects that have the potential to infringe either the European anti-cartel rules (Article 101 (1) TFEU) or the rules against an abuse of dominance (Article 102 TFEU) - depending on whether FFP is viewed to constitute a cartel among football clubs organized by UEFA as an association of undertakings or UEFA is viewed to be a dominant undertaking (Budzinski \& Szymanski 2014). However, the restrictive effects may be justified - and thus fail to infringe European competition rules - if they are inherent and proportional to legitimate objectives (European Commission 2007; Budzinski 2012). The next sections discuss whether FFP meets these three conditions from an economic perspective.

\subsection{Legitimacy: The Objectives of Financial Fair Play}

According to the European Commission (2007: 68), legitimate objectives are usually those that relate to the proper organization and conduct of competitive sport. This may include objectives like ensuring fair sport competitions with equal chances for all teams, ensuring the uncertainty of results by the absence of match-fixing, the protection of the athletes' health, protecting the safety of the spectators, the encouragement of training of young athletes, ensuring of financial stability of sport clubs and teams, the rules of the game (ensuring uniform and consistent exercise of a given sport), etc. (European Commission 2007; Kienapfel \& Stein 2007). Thus, the

\footnotetext{
${ }^{11}$ Since it is money from private investors that is deterred by FFP, whereas all revenue sources that are paid for by the fans remain unchanged (or even increase in importance since money injections from wealthy owners are restricted), a deflatory effect on prices (tickets, broadcasting rights, etc.) cannot be expected in the short run. In the midterm, however, the reduction in absolute talent quality may lead to a sinking willingness-to-pay, in particular for broadcasting rights. Still, this effect may well be mitigated by the lack of close substitutes to top level professional football.

${ }^{12}$ See Budzinski and Szymanski (2014) for a reasoning how UEFA itself may benefit from restricting access to top European leagues to the incumbent superstar clubs and from deterring new challengers.
} 
financial stability of the sporting competitors is explicitly quoted as a legitimate objective. According to UEFA (2012: 2), the objectives of the financial fair play regulations are

- to improve the economic and financial capability of the clubs, increasing their transparency and credibility,

- to place the necessary importance on the protection of creditors and to ensure that clubs settle their liabilities with players, social/tax authorities and other clubs punctually,

- to introduce more discipline and rationality in club football finances,

- to encourage clubs to operate on the basis of their own revenues,

- to encourage responsible spending for the long-term benefit of football, and

- to protect the long-term viability and sustainability of European club football.

These objectives appear to be comfortably in line with the Commission's concept of legitimate objectives, perhaps with the only exception of the objective to encourage clubs to operate on the basis of their own revenues. It may be debatable whether it represents a legitimate objective to limit the sources of financing business investment as long as these sources do not involve taxpayer money. Why should non-revenue based financial means represent an illegitimate source of financing investments? Increases of equity or borrowed capital do represent very usual instruments of financing investments in 'ordinary' business.

Naturally, the listed objectives are the stated objectives of UEFA and in competition policy analyses it is common to look beyond the stated objectives because smart companies will obviously not state anticompetitive (or here: illegitimate) objectives in public. However, I do not want to speculate on UEFA's hidden agendas here and, therefore, I will assume that the criterion of legitimate objective is generally fulfilled. ${ }^{13}$

\subsection{Inherence: Systematic Market Failure in Football?}

\subsubsection{Financial Crisis in Football}

From an economic perspective, the concept of inherence requires to demonstrate that economic competition among professional football clubs without a regulation of investment behavior would systematically fail. Instead, football clubs would systematically engage in irrational, irresponsible and unsustainable (over-)spending. It is important to emphasize that inherence requires systematic market failure and not just individual bad financial management of some clubs. In other words, the restrictive effects of FFP are inherent to the pursued objectives if otherwise the football

\footnotetext{
${ }^{13}$ However, see the contrary assessment by Long (2012: 91-92).
} 
market would display systematic overinvestment. If unrestricted investment inevitably leads to unsustainable overinvestment, then a restriction of investment behavior can be called inherent.

The recent sports economics literature includes a long and controversial discussion about losses and debts in football (inter alia, Frick \& Prinz 2006; Lago et al. 2006; Andreff 2007; Dietl \& Franck 2007; Barajas \& Rodríguez 2010, 2014; Haugen \& Solberg 2010; Szymanski 2010; Drut \& Raballand 2012; Hamil 2014). Some of the contributions as well as general press and media articles list impressive debt figures of single clubs and even accumulated figures for overall leagues. ${ }^{14}$ However, the interpretation of these figures is often rather unclear. In particular the general media discussion (but also some of the more scientific treatments) often lacks a relation of debt figures to asset values of the football clubs, ignoring the rationale behind the usual business practice of working with a certain share of borrowed capital (in particular when a company or a business is growing in commercial terms - as is the football business). The relatively low number and frequency of insolvencies in premier level football leagues does not necessarily support systematic market failure, in particular, since only in very few cases, the football clubs were forced to leave the market (Vöpel 2011). In most of the cases, the losses are eventually covered by private investors. Be it fans or wealthy individuals - as long as losses are covered without injecting taxpayer money, it is hard to see a serious problem from an economic point of view. ${ }^{15}$ In summary, the empirical picture is not as conclusive as it may appear at first sight.

So, what about potential reasons for systematic market failure, in this case systematic overinvestment to an extend that endangers the existence of so many competing clubs that the league itself is in jeopardy. The literature offers quite a number of characteristics and mechanisms of commercial football markets that may cause overinvestment. Some theories serve to explain why single clubs fail to produce a viable investment strategy. For instance, management incompetence due to a preference for hiring former sports stars over business experts (Frick \& Prinz 2006: 72-73), negative shocks due to unexpected failures of revenue sources (Szymanski 2012) or negative externalities from insolvent clubs on other clubs due to financial interrelations in consequence of mutual transfer transactions (Müller et al. 2012: 121-122) are discussed. While all of these explanations have their merits, they cannot explain systematic failure, i.e. inevitable deficiency of the league competition. Financial failures of

\footnotetext{
${ }^{14}$ The UEFA (2011) itself published a so-called benchmarking report stating that more than 50 per cent of the top 650 football clubs in Europe were producing losses, accumulating in 2011 to a sum of $€ 1700$ million.

${ }^{15}$ There have been cases where taxpayer money has been used to save a famous football club from insolvency (for instance, the controversial 2001 Real Madrid case; Gröteke 2004). This represents a competitive concern - one that, however, falls under the state aid control policy. In December 2013, the European Commission started three new in-depth investigations into cases of public funding of several Spanish football clubs (with Real Madrid and Barcelona CF being among them) on the background of a possible violation of state aid rules (European Commission 2013). The questionable public support measures include tax privileges, state guarantees for bank loans, and real estate transactions at unusual conditions.
} 
single competitors (in particular because of mismanagement) are a normal phenomenon and do not constitute market failure.

Furthermore, the sports economics literature offers some theories that are more suited to explain systematic market failure. Firstly, systematic overinvestment may be caused by football clubs behaving as win maximizers instead of profit maximizers (inter alia, Késenne 1996, 2006; Vöpel 2011; Storm 2012). Models of league competition show that, in equilibrium, win maximizing teams invest more into talent than profit maximizing teams and, if the profit maximization equilibrium is defined as the paragon, in this sense win maximizing teams overinvest. Due to the special characteristics of European football, win-maximizing behavior is generally accepted (empirically and in theory) to better describe European football markets than profit-maximizing behavior (which is generally viewed to be a good description of American professional sports leagues). If no profits are extracted from the clubs (non-for-profit character, the goal of maximizing wins), then it is plausible that investment into sporting success is higher than in profit-oriented organizations. However, it is questionable whether this explanation suffices to explain non-viable overinvestment creating a systematic debt-accumulating and insolvency-producing market failure. Even if wins are maximized and, thus, higher investment levels are realized than in the profit maximizing equilibrium, this does not automatically imply that win maximization is pursued unconditionally (in an irrational and irresponsible way). Rational win maximizers will attempt to maximize sporting success under the condition of financial viability. Not maximizing profits is hardly the same as unconditional overinvestment until bankruptcy. In summary, win maximizing behavior alone does not explain systematic market failure; additional factors must be considered.

\subsubsection{A Rat Race?}

Secondly, several authors have characterized competition among football clubs as a deficient rat race and, thereby, emphasized the systematic character of the market failure (in particular Müller et al. 2012; also Vöpel 2011; Sass 2012). ${ }^{16}$ The fundamental idea of the rat race is that competitors compete for a fixed and indivisible reward. Since only the best competitor (the fastest rat) gets the reward (the cheese), the effort levels of all competitors increase without an increase of the output (which is fixed), thus reducing efficiency (Akerlof 1976: 603-606). ${ }^{17}$ Some authors emphasize that competition among football clubs resembles such a rat race because of what they call (strict) positional competition: "there is only one champion and a team's ranking can fall regardless of how well it plays in absolute terms. 'Positional' competition of this kind is similar to a 'rat race'"' (Vöpel 2011: 55). "Unlike most

\footnotetext{
${ }^{16}$ Franck (2013: 9) uses the term zombie race.

${ }^{17}$ Akerlof (1976) applies the rat race concept to a "surrealistic" (603) labor market where workers compete for a fixed wage by providing a fixed amount of output with different speeds. It is crucial for the model results that a higher speed of providing the output does not entail any benefits - otherwise the induced race would not reduce efficiency! The aim of the paper is to provide examples where social structures and perceptions matter for the equilibrium outcome of a market (Akerlof 1976: 617 ) - in the case of the rat race example the social structure is the workers' "desire to have an equilibrium with all workers of the same class" (604; referring to classes of abilities).
} 
common competitive processes, in a rat race additional input - despite being carefully considered within the framework of maximizing individual objectives - is not rewarded in overall terms. This is due to sport leagues exhibiting a remorseless ranking arithmetic, as better positions in the table cannot be shared and clubs are stringently banished to inferior ranks" (Müller et al. 2012: 121). This theory indeed provides a reasoning involving systematic market failure: if the aspiration levels of the teams do not match the available ranking positions (i.e. more than one teams wants to win the championship, etc.), the strict positional competition necessarily leads (i) to efforts exceeding the rewards (systematic overinvestment) and (ii) to an increasing mismatch between investment and reward in the course of time (systemic debt accumulation) as the teams stick to a risk-friendly gambling for success (Whitney 1993; Dietl \& Franck 2007).

However, the crucial question is whether the necessary conditions for a rat race are suitable assumptions for commercial football competition. The two conditions are:

- a constant reward that cannot be increased by the absolute level of efforts (thus, it is a matter of allocation - who will get the reward - and not of growth) and

- the increasing efforts are waste, i.e. they do not entail any benefit (other than the fixed reward).

The first condition requires that the revenues of a football club strictly depend on the position it achieves in the final league ranking. Furthermore, a higher position in the ranking is strictly associated with a higher reward (revenue). Only relative effort (compared to the competitors) matters for the achieved revenue level and not absolute efforts. These are the characteristics of the rat race-resembling strict positional competition. In order to discuss the accuracy of these characteristics for competition among football clubs, a look at the revenue sources (for instance, UEFA's relevant revenues, see table 1 ) is helpful.

- Gate revenues depend on stadium attendance figures, which are certainly related to sporting success but also depend on other factors like popularity of the club, attractiveness of the team (e.g. offensive play), (home) market size, advertising activities of the club, pricing strategies, etc. Thus, this revenue type does not strictly depend on the ranking position. It is well possible - and empirically supported - that lower ranking clubs realize higher ticket revenues than higher ranking clubs.

- Revenues from sponsorship and advertising also do not strictly depend on ranking positions. Sporting success certainly helps but other factors like negotiation skills, popularity of the club, size of the local industry, etc., are of significant relevance as well. Again, lower ranking clubs can - and do quite frequently - enjoy higher revenues of this type than higher ranking clubs.

- Revenues from broadcasting rights represent the revenue type where the strict relation of ranking position and revenue volume is best fulfilled - at least in systems of centralized marketing of broadcasting rights. In these systems (like in Germany, England or on the UEFA level), the league as whole collects the individual broadcasting rights from the teams, bundles them and sells them 
out of one hand to the media. Then, the revenues are allocated among the league members according to a collectively agreed upon allocation mechanism. Typically, this allocation mechanism provides money according to ranking positions, so that teams' rewards indeed strictly increase with their ranking position. Furthermore, the allocation mechanisms usually include considerable discontinuities, i.e. one position better is associated with an over-proportional increase in reward (e.g. winning the championship or qualifying for a European competition; in the negative sense, relegation implies an over-proportional loss of revenues). In summary, this type of revenues indeed fits the concept of strict positional competition - under the condition of centralized marketing ${ }^{18}$.

- Commercial activities' revenues, again, do not depend strictly on ranking positions.

- Other operating income and finance income do not depend strictly on ranking positions as well.

Among all of UEFA's relevant revenue sources merely one single revenue source, revenues from collectively sold broadcasting rights, mirrors the necessary condition of a rat race-styled positional competition. Extending the discussion to monetary injections from benefactors and other "non-relevant" (according to FFP) sources further loosens the strict dependence of income on the reached position in the final league standings. ${ }^{19}$ Without any doubt, success helps to create higher revenues, however, this is a normal (and beneficial) element of economic competition. Decisively, the total reward is not fixed at all. Next to sporting success, there are various ways how clubs can increase their different types of revenues. Thus, the first condition for a rat race-deficiency is clearly not met.

Note that the only revenue type that fits into the logic of positional competition only does so because UEFA (and some of the national football associations) designed the mechanism to allocate the money from the collectively sold broadcasting rights (which constitutes a cartel raising anticompetitive concerns ${ }^{20}$ ) in exactly such a way! In other words, the only element of systematic overinvestment incentives does not originate from market competition but is introduced against the market forces by the market-internal regulatory agency itself. From this perspective, ceteris paribus, overinvestment does not appear to be inherent to football competition - instead it appears to be inherent to other UEFA regulations.

\footnotetext{
${ }^{18}$ In systems of individual marketing of broadcasting rights, there is no strict relation between ranking position and revenues since other factors (popularity, attractiveness, size of the local market, fan base, etc.) come into play.

${ }^{19}$ In other words, by excluding these revenue types from the break even condition, UEFA's FFP regulations may actually strengthen the rat race elements instead of combating them. However, the effect would probably not be very relevant in its magnitude.
}

${ }^{20}$ See e.g. European Commission (2003), Massey (2007) and Budzinski (2012). 
A brief look on the second condition for a deficient rat race-type of competition indicates that it is probably not met either. The increase in effort of all teams increases the quality of talent and play and, thus, creates benefits for fans and players (salaries). In contrast to the reasoning of the rat race advocates, the increasing effort does not produce the same output (and thus reduce efficiency). Instead, it produces a higher quality output (Szymanski 2014: 5). In turn, this should increase the willingness-to-pay of fans and (consequently) media which draws a connection to the "fixed" reward that, then, is not fixed in a dynamic notion. And, indeed, revenues from all types, but especially from broadcasting rights, have been growing considerably in recent years.

While the conditions of a systematically-deficient rat race are not given in football markets, there is some controversy whether the contest character of sports competition inherently entails incentives for irresponsible and unsustainable overinvestment (pro: Dietl et al. 2008; Franck 2013; contra: Madden 2012; Peeters \& Szymanski 2012, 2014a, 2014b; Szymanski 2014).

\subsubsection{Systematic Bail-outs?}

Thirdly, there is a stream of the literature that views systematic market failure rooted in so-called soft budget constraints (Andreff 2007; Storm 2012; Storm \& Nielsen 2012; Franck 2013). The core idea is that there is a systematic bail-out for insolvent football clubs, so that their managers - in anticipation of the bail-out - systematically fail to consider the budget constraint when deciding on expenses. This represents a type of a moral hazard problem that is caused by a mismatch of decision competency and liability for the decision's consequences. As a result, the soft budget constraint syndrome causes systematic and non-viable overinvestment. In analogy to the toobig-to-fail phenomenon in 'ordinary' markets (and, in particular, in banks markets), it could be claimed that football clubs are too-prominent-to-fail (Budzinski \& Müller 2013) and can rely on being rescued.

Notwithstanding the justified criticism that football markets do not resemble postsocialist transformation markets (to which the soft budget constraint syndrome originally applied) to a sufficient degree to apply this theory (Szymanski 2014: 5), the underlying argument may still have some merit. A crucial issue is the identity of the bail-out providers. In order to classify bail-outs as systematic market failure, there must be some systematic (and not just incidental) bail-out activity. Franck (2013: 1119) names the state and private benefactors as supporting organizations providing the bail-outs. With respect to the injection of taxpayer money, Franck (2013: 12-14) refers to unpaid overdue taxes and social security contributions by Spanish football clubs as evidence. While he is absolutely right in his criticism of the lax enforcement practice of Spanish authorities and the resulting moral hazard problems, it is difficult 
to see how this represents a market failure (and not a regulation failure) - in particular beyond the special case of Spain. ${ }^{21}$ Furthermore, it does not justify the breakeven rule of FFP in the sense of the inherence concept. The no overdue payables rule of FFP suffices to take care of this specific problem.

A much more sophisticated problem is political-economic reasoning that local politicians experience incentives to support 'their' clubs in order to please voters or reap locational benefits of having a famous and successful football club (Franck 2013: 1517). If the existing state aid rules fail to deal with this problem (which would need to be analyzed first - and the European Commission is currently investigating the Spanish cases), this may present a justification for limiting the relevant income by excluding monetary or non-monetary injections financed by taxpayers. Still, the break-even rule goes significantly beyond doing this.

And this relates to the second group viewed to be responsible for bail-outs - the private benefactors or sugar daddies (Lang et al. 2011; Franck \& Lang 2012; Franck 2013: 17-19). However, from a competition economics perspective, it is difficult to argue against voluntary equity injections by private investors. The individual decision where and when to place an investment represents a cornerstone of the efficiency advantages of market competition. If financial distress is the concern, then financial injections into equity - strengthening the financial fundament of the clubs in question - actually alleviates the problem. Not surprisingly, Madden (2012) derives positive welfare effects of benefactors' money injections in a theoretical model (see with different modeling also Peeters \& Szymanski 2012, 2014a). From an economic point of view, it seems difficult to discriminate between (promoted) sponsorship money and (unwanted) equity money. In effect, both represent financial means provided by private actors because of expected utility increases worth the money. Discriminating between commercial and personal motives is difficult and often arbitrary, does not alter the effects - and becomes eventually blurry when considering the engagement of Red Bull buying into clubs like RB Salzburg (formerly Austria Salzburg) and $\mathrm{R}$ (asen)B(allsport) Leipzig (formerly SSV Markranstädt).

In summary, the too-prominent-to-fail issue may represent a concern for the functioning of competition among professional football clubs. However, more research is needed into how systematic this phenomenon is: are all clubs too prominent to fail? Or does it affect just specific ones? And is there really a problem beyond enforcing state aid rules in order to discipline the use of taxpayer money? Altogether, from an economics perspective, there is little support for FFP - and, in particular, the discriminatory investment restrictions of the break-even rule - being inherent to the objectives of rational, responsible and viable financial behavior.

\subsection{Proportionality: Are There Less Restrictive Alternatives?}

\footnotetext{
${ }^{21}$ Indeed, as mentioned earlier, the European Commission has recently started an in-depth investigation in these cases, investigating whether European state aid rules got violated (European Commission 2013; for an early economic analyses of the general problem see Gröteke 2004).
} 
Even if - for the sake of the argument - inherence was accepted, the restrictive effects of the financial fair play rules would need to be proportional to the legitimate objectives. Establishing proportionality would require two things. Firstly, the objectives must be important enough to justify the restrictive effects. If competition among football clubs without investment restrictions was necessarily causing irresponsible and non-viable financial behavior with an inherent market failure (which is doubtful, see section 3.2.), then the objectives of restoring rational, responsible and sustainable investment strategies may be important enough to justify the restrictive effects. Proportionality is certainly unproblematic in regard to the no overdue payables rule since the restrictive effects of this element of FFP are marginal if existing at all. The more difficult assessment relates to the break-even rule, discriminating between different types of revenues and monetary injections. Its effects of protecting incumbents, cementing the market structure and shifting rents from players to clubs (see section 2) are considerably restrictive so that justifying them in terms of proportionality would require substantial objectives, for instance, relating to the fundamental functioning of the market. The weak link, however, remains the inconclusive empirical evidence for and the questionable theoretical reasoning of a systematic market failure (see section 3).

Secondly, the restrictive effects can only be called proportional to the objectives if there does not exist any less restrictive alternative to achieve the same goals. In the context of FFP, this would ask for regulatory alternatives for combating overinvestment without restrictive effects on players' salaries, market access, competition intensity and, at the end of the day, consumer welfare. According to Dietl et al. (2008) overinvestment becomes more probable if

- the correlation between talent investment and winning probability tightens,

- simultaneous investments dominate consecutive investments,

- the league has an open structure with promotion and relegation (in contrast to an American-style closed league), and

- revenue differentials both within a league and between hierarchical leagues increase.

Note, however, that overinvestment here relates to the paragon of a profit-maximizing equilibrium and does not necessarily represent unsustainable and irresponsible (non-viable) overinvestment (and thus does not necessarily imply systematic market failure). Notwithstanding this qualification, the results reveal alternative avenues to limit overinvestment incentives. While the first three factors may be difficult to shape via regulation (or entail even more restrictive effects than FFP), the fourth factor the magnitude of the revenue differentials - provides a particularly interesting starting point from a competition economics perspective. The reason is that revenue differentials within UEFA club competitions and between the UEFA leagues and the national leagues that result from the distribution of broadcasting rights revenues are by and large not the result of market processes in the current institutional framework of European football. Instead, these revenue differentials are defined and implemented by UEFA (and the national football associations) as a part of its centralized 
marketing strategy (the cartel for selling broadcasting rights). At the same time, revenue differentials from the allocation of broadcasting revenues represent a significant part of total revenue differentials. Moreover, it is exactly this type of revenue where a strict relation between ranking position and revenue volume applies (see section 3.2.2.). So, there is the interesting situation that one of the main factors setting incentives for overinvestment is rooted in UEFA's regulation and policy itself. A change in the revenue sharing policy, thus, is likely to alleviate overinvestment incentives and provide an avenue to achieving the legitimate objectives without (additional ${ }^{22}$ ) restrictive effects (Schokkaert 2013). Other potentially less restrictive instruments that were suggested in the literature include changes in the competition format, equal and non-discriminatory budget caps, reduction of compensation packages, transfer payment caps, and so-called luxury taxes (Lindholm 2010: 208-211; Schokkaert 2013). ${ }^{23}$

However, the FFP regulations themselves may offer routes for less restrictive interventions achieving similar objectives. Perhaps, the no overdue payables rule alone would already suffice to achieve the legitimate objectives of FFP - without causing the restrictive effects of the break even rule. And even the break even rule can be changed in a way that most of the competition concerns would probably be resolved. The unlimited inclusion of equity-increasing injections as relevant income into the FFP scheme (see table 1 of section 2) might already suffice to alleviate the competition concerns to an extent that the remaining, less severe restrictive effects may qualify to be proportional to legitimate objectives motivated by too-prominent-to-fail problems.

In summary, it will be difficult to reason that the FFP regulations in its current shape are not excessive when compared to alternative instruments achieving the same legitimate objectives. This criticism does not encounter all elements of FFP. The no overdue payables rule is likely to be completely unproblematic in competition terms. While the break even rule is much more crucial in this regard, it is particularly the according to the economic analysis unnecessary - restrictive and selective character of the revenue sources that are relevant in UEFA's diction that causes most of the concerns.

\section{Reflection and Conclusion}

\footnotetext{
${ }^{22}$ The broadcasting rights cartel itself comes along with restrictive effects on competition. However, the European Commission (2003) cleared it under conditions and obligations (critical discussion: Massey 2007; Budzinski 2012). Since it exists anyway (as a consequence), it may solve the overinvestment problem as well without additional intervention.

${ }^{23}$ It would require a comparative economic analysis for each of these suggested instruments in order to determine whether they are indeed less restrictive.
} 
Even if the FFP regulations fail to meet the conditions of inherence and proportionality of its restrictive effects to the legitimate objectives, then there remains the possibility to accommodate them under the conditions of Article 101 (3) TFEU ${ }^{24}$. If FFP enhances allocative and dynamic efficiency, provides a fair share of these benefits to consumers and if the benefits are specific to the agreement and competition is not significantly impeded, then the European Commission may allow the agreement in total or under conditions and obligations. Whether FFP meets the conditions of Article 101 (3) TFEU has been subject to analysis in the competition law literature with pessimistic conclusions about its suitability for such an antitrust exemption (Lindholm 2010: 211; Long 2012: 96-100). This view is supported by the economic perspective in this paper, pointing to considerable anticompetitive effects for consumers and competition (violating the consumer benefits and no impediment of competition criteria) as well as emphasizing the existence of less restrictive alternatives (violating the cartel specificity criterion). Furthermore, the questionable market failure reasoning (section 3) casts doubt upon the probability of efficiency-enhancing benefits of FFP (Szymanski 2014).

Altogether, it appears to be doubtful that UEFA's financial fair play regulations (in their current shape) stand in full compliance with European competition rules - at least from an economic perspective. Against this background, it appears to be a bit surprising that EU Competition Commissioner Joaquín Almunia publicly sided with UEFA president Michel Platini in praising the FFP initiative (Almunia 2012; Almunia \& Platini 2012). However, at a closer look, the statements explicitly merely mention FFP's compliance with state aid law (Long 2012: 84-86). The concerns, however, address the laws against private restraints of competition (anti-cartel rules and abuse control). Given the complaint and the court proceeding initiated by player agent Daniel Striani, the Commission is forced to take a closer look at the competition law compliance of FFP and it will be interesting to see the outcome. From the perspective taken in this paper, a modification of FFP broadening the relevant income concept of FFP's break even rule represents sort of a minimum requirement for alleviating the most important anticompetitive concerns (incumbent protection effect and consolidation effect; partly also salary reduction effect). A commitment along these lines then may be enough to appease a Commission that does appear to be taking a sympathetic stance towards the fundamental ideas of FFP. ${ }^{25}$ Whether such a minimum modification of FFP would represent an optimal outcome from a competition economics perspective is more difficult to say and in particular depends on the comparative assessment of alternatives like (i) reliance on the FFP element no overdue payables rule alone in order to combat imminent insolvency risks, (ii) modifying the allocation mechanism of broadcasting rights revenues in order to reduce revenue differentials (and thus overinvestment incentives), or (iii) the implementation of other instruments (luxury tax, non-discriminatory budget cap, etc.).

\footnotetext{
${ }^{24}$ This requires to classify FFP as an agreement among undertakings and/or associations of undertakings. See for a discussion Budzinski and Szymanski (2014).

${ }^{25}$ Furthermore, the Commission has recently put focus on reaching mutual agreements with the parties to a case instead of more unilaterally enforcing competition rules (Budzinski \& Kuchinke 2012).
} 


\section{References}

Akerlof, George (1976), The Economics of Caste and of the Rat Race and other Woeful Tales, in: The Quarterly Journal of Economics, Vol. 90 (4), pp. 599-617.

Almunia, Joaquín (2012), Letter to Michel Platini, http://ec.europa.eu/competition/sectors/sports/letter_almunia_en.pdf.

Almunia, Joaquín \& Platini, Michel (2012), Joint Statement, http://ec.europa.eu/competition/sectors/sports/joint_statement_en.pdf.

Andreff, Wladimir (2007), French Football - A Financial Crisis Rooted in Weak Governance, Journal of Sports Economics, Vol. 8 (6), pp. 652-661.

Barajas, Ángel \& Rodríguez, Plácido (2010), Spanish Football Clubs' Finances: Crisis and Player Salaries, in: International Journal of Sport Finance, Vol. 5 (1), pp. 5266.

Barajas, Ángel \& Rodríguez, Plácido (2014), Spanish Football in Need of Financial Therapy: Cut Expenses and Inject Capital, in: International Journal of Sport Finance, Vol. 9 (1), pp. 73-90.

Budzinski, Oliver (2012), The Institutional Framework for Doing Sports Business: Principles of EU Competition Policy in Sports Markets, in: International Journal of Sport Management and Marketing, Vol. 11 (1-2), pp. 44-72.

Budzinski, Oliver \& Kuchinke, Björn A. (2012), Deal or no Deal: Consensual Arrangements as an Instrument of European Competition Policy?, in: Review of Economics, Vol. 63 (3), pp. 265-292.

Budzinski, Oliver \& Müller, Anika (2013), Finanzregulierung und internationale Wettbewerbsfähigkeit: Der Fall Deutsche Bundesliga, in: R. Dewenter, J. Haucap \& C. Kehder (eds.), Wettbewerb und Regulierung in Medien, Politik und Märkten, Nomos: Baden-Baden 2013, pp. 261-290.

Budzinski, Oliver \& Szymanski, Stefan (2014), Are Restrictions of Competition by Sports Associations Horizontal or Vertical in Nature? Manuscript.

Coates, D., Humphreys, B. R. \& Zhou, L. (2014): Outcome Uncertainty, Referencedependent Preferences and Live Game Attendance, in: Economic Inquiry (forthcoming).

Dietl, Helmut M. \& Franck, Egon (2007), Governance Failure and Financial Crisis in German Football, in: Journal of Sports Economics, Vol. 8 (6), pp. 662-669.

Dietl, H. M., Franck, E. \& Lang, M. (2008), Overinvestment in Team Sports Leagues: A Contest Theory Model, in: Scottish Journal of Political Economy, Vol. 55, 353368.

Drut, Bastien \& Raballand, Gaël (2012), Why Does Financial Regulation Matter for European Professional Football Clubs?, in: International Journal of Sport Management and Marketing, Vol. 11 (1), pp. 73-88.

Dupont, Jean-Louis (2013), Football's Anticompetitive Streak, in: The Wall Street Journal, 2013-03-25. 
European Commission (2003), COMP/C.2-37.398 - Joint Selling of the Commercial Rights of the UEFA Champions League, Commission Decision, 2003/778/EC, Brussels.

European Commission (2007), The EU and Sport: Background and Context, Commission Staff Working paper accompanying the White paper on Sport, SEC(2007)935, Brussels.

European Commission (2013), State Aid: Commission Opens In-depth Investigation into Public Funding of Certain Spanish Professional Football Clubs, Press Release IP/13/1287, 18/12/2013.

Franck, E. (2013), Financial Fair Play in European Club Football - What is it all about?, UZH Business Paper Working Series No. 328, University of Zurich.

Franck, Egon \& Lang, Markus (2012), Theoretical Analysis of the Influence of Money Injections on Risk Taking, Discussion Paper ... (in: Scottish Journal of Political Economy

Frick, Bernd \& Prinz, Joachim (2006), Crisis? What Crisis? Football in Germany, in: Journal of Sports Economics, Vol. 7, pp. 60-75.

Gröteke, Friedrich (2004), Zur Frage der Behandlung von Regulierungen in der Beihilfenkontrolle und mögliche Konsequenzen des Grundstücksverkaufs von Real Madrid, in: Finanzreform, Vol. 1 (11), pp. 146-159.

Hamil, Sean (2014), Financial Fair Play - Why Loss-Making Is a Problem: The Example of the English Football League, in: O. Budzinski \& A. Feddersen (eds.), Contemporary Research in Sports Economics: Proceedings of the $5^{\text {th }}$ ESEA Conference, Frankfurt a.M.: Lang, forthcoming.

Haugen, Kjetil H. \& Solberg, Harry A. (2010), The Financial Crisis in European Football: A Game Theoretic Approach, in: European Sport Management Quarterly, Vol. 10 (5), pp. 553-567.

Késenne, S. (1996), League Management in Professional Team Sports with Win Maximizing Clubs, in: European Journal for Sports Management, 2, 14-22.

Késenne, S. (2006). The Objective Function of a Team. In W. Andreff, \& S. Szymanski (Eds.), Handbook of the Economics of Sport (pp. 601_609). Cheltenham, UK: Edward Elgar Publishing.

Kienapfel, P. and Stein, A. (2007), The Application of Articles 81 and 82 EC in the Sport Sector, in: Competition Policy Newsletter, No. 3, pp.6-14.

Könecke, T. \& Schubert, M. (2014), Socio-economic Doping and Enhancement in Sport: A Case-based Analysis of Dynamics and Structural Similarities in: O. Budzinski \& A. Feddersen (eds.), Contemporary Research in Sports Economics: Proceedings of the $5^{\text {th }}$ ESEA Conference, Frankfurt a.M.: Lang, forthcoming.

Lago, U., Simmons, R., \& Szymanski, S. (2006), The Financial Crisis in European Football, in: Journal of Sports Economics, Vol. 7, pp. 3-12. 
Lang, M., Grossman, M. \& Theiler, P. (2011): The Sugar Daddy's Game: How Wealthy Investors Change Competition in Professional Team Sports, in: Journal of Institutional and Theoretical Economics, Vol. 167, 4, pp. 557-577.

Lindholm, Johan (2010), The Problem with Salary Caps under European Union Law: The Case against Financial Fair Play, in: Texas Review of Entertainment \& Sports Law, Vol. 12 (2), pp. 189-213.

Long, Clinton R. (2012), Promoting Competition or Preventing it? A Competition Law Analysis of UEFA's Financial Fair Play Rules, in: Marquette Sports Law Review, Vol. 23 (1), pp. 75-101

Madden, Paul (2012), Welfare Consequences of "Financial Fair Play" in a Sports League with Benefactor Club Owners, in: Journal of Sports Economics, online first, doi:10.1177/1527002512465759.

Massey, P. (2007), Are Sports Cartels Different?, in: World Competition, Vol. 30 (1), pp. 87-106.

Maxcy, Joel (2014), The American View on Financial Fair Play, in: O. Budzinski \& A. Feddersen (eds.), Contemporary Research in Sports Economics: Proceedings of the $5^{\text {th }}$ ESEA Conference, Frankfurt a.M.: Lang, forthcoming.

Müller, J. Christian, Lammert, Joachim \& Hovemann, Gregor (2012), The Financial Fair Play Regulations of UEFA: An Adequate Concept to Ensure the Long-Term Viability and Sustainability of European Club Football?, in: International Journal of Sports Finance, Vol. 7, pp. 117-140.

Neale, W. C. (1964), The Peculiar Economics of Professional Sports, in: The Quarterly Journal of Economics, Vol. 78 (1), pp. 1-14.

Peeters Thomas \& Szymanski, Stefan (2012), Vertical Restraints in Soccer: Financial Fair Play and the English Premier League, Working Papers 2012028, University of Antwerp, Faculty of Applied Economics.

Peeters, T. \& Szymanski, S. (2014a), Financial Fair Play in European Football, in: Economic Policy, forthcoming.

Peeters, T. \& Szymanski, S. (2014b), Financial Fair Play: Winners and Losers on and off the Pitch, in: O. Budzinski \& A. Feddersen (eds.), Contemporary Research in Sports Economics: Proceedings of the $5^{\text {th }}$ ESEA Conference, Frankfurt a.M.: Lang, forthcoming.

Preuss, H., Haugen, K., \& Schubert, M. (2012): UEFA Financial Fair Play: The Curse of Regulation, Working Paper No. 7, Institute of Sport Science, Mainz.

Rottenberg, Simon (1956), The Baseball Player's Labor Market, in: Journal of Political Economy, Vol. 64 (3), pp. 242-258.

Sass, Markus (2012), Long-term Competitive Balance under UEFA Financial Fair Play Regulations, University of Marburg, Working Paper Series, No. 5/2012.

Schokkaert, Jeroen (2013), Financial Fair Play, Alternative Instruments and Competitive Balance, http://footballperspectives.org/financial-fair-play-alternative-instruments-and-competitive-balance (accessed 2014-03-04, 14.32). 
Storm, Rasmus K. (2012), The Need of Regulating Professional Soccer in Europe: A Soft Budget Constraint Argument, in: Sport, Business and Management: An International Journal, Vol. 2, pp. 21-38.

Storm, Rasmus K. \& Nielsen, Klaus (2012), Soft Budget Constraints in Professional Football, in: European Sport Management Quarterly, Vol. 12, pp. 183-201.

Szymanski, Stefan (2010), The Financial Crisis and English Football: The Dog that will not Bark, in: International Journal of Sports Finance, Vol. 5 (1), pp. 28-40.

Szymanski, Stefan (2012), Insolvency in English Professional Football: Irrational Exuberance or Negative Shocks?, Discussion Paper ...

Szymanski, Stefan (2014), Fair Is Foul: A Critical Analysis of UEFA Financial Fair Play, Manuscript.

UEFA (2011), The European Club Licensing Benchmarking Report, Nyon: UEFA.

UEFA (2012), UEFA Club Licensing and Financial Fair Play Regulations, Edition 2012, Nyon: UEFA.

UEFA (2014), Procedural Rules Governing the UEFA Club Financial Control Body, Edition 2014, Nyon: UEFA.

Vöpel, Henning (2011), Do We Really Need Financial Fair Play in European Club Football? An Economic Analysis, in: CESifo DICE Report, Vol. 9 (3), pp. 54-60.

Weatherill, Stephen (2006), Anti-doping Revisited - the Demise of the Rule of 'Purely Sporting Interest'? in: European Competition Law Review, Vol. 27, pp. 645 ff.

Whitney, James D. (1993), Bidding till Bankrupt: Destructive Competition in Professional Team Sports, in: Economic Inquiry, Vol. 31 (1), pp. 100-115.

*** This paper will be published in:

Contemporary Research in Sports Economics - Proceedings of the $5^{\text {th }}$ ESEA Conference

Oliver Budzinski \& Arne Feddersen (eds.)

Frankfurt a.M.: Lang International Publishers 2014

\section{Prolog}

1. Introduction (Oliver Budzinski \& Arne Feddersen)

Financial Fair Play in European Football 
2. Financial Fair Play: Winners and Losers on and off the Pitch (Thomas Peeters \& Stefan Szymanski)

3. Financial Fair Play - Why Loss-Making Is a Problem: The Example of the English Football League (Sean Hamil)

4. The American View on Financial Fair Play (Joel Maxcy)

5. The Competition Economics of Financial Fair Play (Oliver Budzinski)

6. Socio-economic Doping and Enhancement in Sport: A Case-based Analysis of Dynamics and Structural Similarities (Thomas Könecke \& Mathias Schubert)

Performance and Competition in International Football

7. In Urgent Need of Change? Within-season Coach Dismissals, Regression-to-themean, and Performance of Football Teams (Nikolaus Beck \& Mark Meyer)

8. Competitive Balance and Attention Level Effects: Theoretical Considerations and Preliminary Evidence (Tim Pawlowski \& Oliver Budzinski)

9. Spill-overs? Economic Progress, Football Facilities and the 2011 Asia Cup (Peter Ochieng)

New Research on Individual Sports

10. Analysis of Event Visitors' Expenditure Patterns: The Case of the Three FIS Ski Jumping World Cup Events 2013 (Grzegorz Kwiatkowski \& Ove Oklevik)

11. Public Opinion on Doping in Cycling: Differences among Population Groups (Daam van Reeth \& Wim Lagae)

12. The Economics of Motorsport Centers (Anika Müller \& Oliver Budzinski)

The Economics of Sports Events

13. The Winner's Curse in Sports Economics (Wladimir Andreff)

14. Sports on the Air: A GARCH Examination of the Impact of Broadcasts of Live Sporting Events on Television Audience Sizes (José Baños, Levi Pérez, Victor Puente \& Plácido Rodríguez)

15. Gridiron Games: A Case Analysis of Turf War Issues and the Economic, Social, Cultural, and Political Incentives for Government Subsidization (Christopher M. Keshock, Brooke Forester \& Shelley Holden) 
Epilogue

16. A Survey of Five Years of ESEA Conferences (Daam van Reeth)

\section{Diskussionspapiere aus dem Institut für Volkswirtschaftslehre der Technischen Universität IImenau}

Nr. 30 Steinrücken, Torsten: Die Legitimation staatlicher Aktivität durch vertragstheoretische Argumente: Anmerkungen zur Kritik an der Theorie des Gesellschaftsvertrages, März 2003.

Nr. 31 Steinrücken, Torsten; Jaenichen, Sebastian: Heterogene Standortqualitäten und Signalstrategien: Ansiedlungsprämien, Werbung und kommunale Leuchtturmpolitik, April 2003.

Nr. 32 Steinrücken, Torsten: Funktioniert ,fairer' Handel? Ökonomische Überlegungen zum alternativen Handel mit Kaffee, Juli 2003.

Nr. 33 Steinrücken, Torsten; Jaenichen, Sebastian: Die Wiederentdeckung der Zweitwohnsitzsteuer durch die Kommunen - zu Wirkungen und Legitimation aus ökonomischer Sicht, September 2003.

Nr. 34 Rissiek, Jörg; Kressel, Joachim: New Purchasing \& Supply Chain Strategies in the Maintenance, Repair and Overhaul Industry for Commercial Aircraft, September 2003.

Nr. 35 Steinrücken, Torsten; Jaenichen, Sebastian: Europäische Beihilfekontrolle und Public Utilities - Eine Analyse am Beispiel öffentlicher Vorleistungen für den Luftverkehr, Dezember 2003.

Nr. 36 Voigt, Eva; GET UP: Gründungsbereitschaft und Gründungsqualifizierung - Ergebnisse der Studentenbefragung an der TU Ilmenau, April 2004.

Nr. 37 Steinrücken, Torsten; Jaenichen, Sebastian: Levelling the playing field durch staatliche Beihilfen bei differierender Unternehmensmobilität, Mai 2004.

Nr. 38 Steinrücken, Torsten; Jaenichen, Sebastian: Sekundärwirkungen von Unternehmensansiedlungen - Eine Beurteilung staatlicher Aktivität beim Auftreten paretorelevanter Nettoexternalitäten, Juni 2004.

Nr. 39 Kallfaß, Hermann H.: Wettbewerb auf Märkten für Krankenhausdienstleistungen - eine kritische Bestandsaufnahme, Juni 2004.

Nr. 40 Engelmann, Sabine: Internationale Transfers und wohlfahrtsminderndes Wachstum, September 2004. 
Nr. 41 Steinrücken, Torsten; Jaenichen, Sebastian: Zum Einfluss von Ausländern auf die Wirtschaftsleistung von Standorten - Ist Zuwanderung ein Weg aus der ostdeutschen Lethargie?, Oktober 2004.

Nr. 42 Steinrücken, Torsten; Jaenichen, Sebastian: Wer ist wirklich reich? - Zu Problemen der Wohlfahrtsmessung durch das Bruttoinlandsprodukt, April 2005.

Nr. 43 Steinrücken, Torsten; Jaenichen, Sebastian: Wo bleiben die Subventionssteuern? - Probleme des Beihilfenrechts und ein alternatives Regulierungskonzept, Mai 2005.

Nr. 44 Jaenichen, Sebastian; Steinrücken, Torsten; Schneider, Lutz: Zu den ökonomischen Wirkungen gesetzlicher Feiertage - Eine Diskussion unter besonderer Berücksichtigung der Arbeitszeitpolitik, Juni 2005.

Nr. 45 Kuchinke, Björn A.: Qualitätswettbewerb zwischen deutschen Akutkrankenhäusern unter besonderer Berücksichtigung von DRG und Budgets, Juni 2005.

Nr. 46 Kuchinke, Björn A.; Walterscheid, Heike: Wo steht der Osten? Eine ökonomische Analyse anhand von Wohlfahrts- und Happinessindikatoren, Juni 2005.

Nr. 47 Kuchinke, Björn A.; Schubert, Jens M.: Staatliche Zahlungen an Krankenhäuser: Eine juristische und ökonomische Einschätzung nach Altmark Trans und der Entscheidung der Kommission vom 13.7.2005, August 2005.

Nr. 48 Steinrücken, Torsten; Jaenichen, Sebastian: Überkapazitäten zur Absicherung politischer Risiken und Instrumente finanzwirtschaftlicher Gegensteuerung, November 2005.

Nr.49 Jaenichen, Sebastian; Steinrücken, Torsten: Opel, Thüringen und das Kaspische Meer, Januar 2006.

Nr. 50 Kallfaß, Hermann H.: Räumlicher Wettbewerb zwischen Allgemeinen Krankenhäusern, Februar 2006.

Nr. 51 Sickmann, Jörn: Airport Slot Allocation, März 2006.

Nr. 52 Kallfaß, Hermann H.; Kuchinke, Björn A.: Die räumliche Marktabgrenzung bei Zusammenschlüssen von Krankenhäusern in den USA und in Deutschland: Eine wettbewerbsökonomische Analyse, April 2006. 
Nr. 53 Bamberger, Eva; Bielig, Andreas: Mehr Beschäftigung mittels weniger Kündigungsschutz? Ökonomische Analyse der Vereinbarungen des Koalitionsvertrages vom 11. 11. 2005, Juni 2006.

Nr. 54 Jaenichen, Sebastian; Steinrücken, Torsten: Zur Ökonomik von Steuergeschenken - Der Zeitverlauf als Erklärungsansatz für die effektive steuerliche Belastung, Dezember 2006.

Nr. 55 Jaenichen, Sebastian; Steinrücken, Torsten: Wirkt eine Preisregulierung nur auf den Preis? Anmerkungen zu den Wirkungen einer Preisregulierung auf das Werbevolumen, Mai 2007.

Nr. 56 Kuchinke, B. A.; Sauerland, D.; Wübker, A.: Determinanten der Wartezeit auf einen Behandlungstermin in deutschen Krankenhäusern - Ergebnisse einer Auswertung neuer Daten, Februar 2008.

Nr. 57 Wegehenkel, Lothar; Walterscheid, Heike: Rechtsstruktur und Evolution von Wirtschaftssystemen - Pfadabhängigkeit in Richtung Zentralisierung?, Februar 2008.

Nr. 58 Steinrücken, Torsten; Jaenichen, Sebastian: Regulierung und Wohlfahrt in einem Modell mit zwei Aktionsparametern, März 2008.

Nr. 59 Lehnert, Ninja M.: Externe Kosten des Luftverkehrs - Ein Überblick über den aktuellen Stand der Diskussion, April 2008.

Nr. 60 Walterscheid, Heike: Reformbedarf etablierter Demokratien im Kontext dezentralisierter Gesellschaftssysteme - Grundlegende Hindernisse bei Steuersystemreformen", April 2010.

Nr. 61 Walterscheid, Heike; Wegehenkel, Lothar: Kostenstruktur, Zahlungsbereitschaft und das Angebot von Mediengütern auf Medienmärkten, Juni 2008.

Nr. 62 Walterscheid, Heike; Wegehenkel, Lothar: Wohlstand der Nationen und handlungsrechtliche Struktur eines Gesellschaftssystems, September 2008.

Nr. 63 Dewenter, Ralf; Haucap, Justus; Wenzel, Tobias: Indirect Network Effects with Two Salop Circles: The Example oft the Music Industry, Juni 2009.

Nr. 64 Dewenter, Ralf; Jaschinski, Thomas; Wiese, Nadine: Wettbewerbliche Auswirkungen eines nichtneutralen Internets, Juli 2009.

Nr. 65 Dewenter, Ralf; Haucap, Justus; Kuchinke, Björn A.: Das Glück und Unglück von Studierenden aus Ost- und Westdeutschland: Ergebnisse einer Befragung in Ilmenau, Bochum und Hamburg, Oktober 2009. 
Nr. 66 Kuchinke, Björn A.; Zerth, Jürgen; Wiese, Nadine: Spatial Competition between Health Care Providers: Effects of Standardization, Oktober 2009.

Nr. 67 Itzenplitz, Anja; Seifferth-Schmidt, Nicole: Warum Klimakonferenzen scheitern, aber dennoch zum Wohl des Weltklimas kooperiert wird, Juli 2010.

Nr. 68 Kallfaß, Hermann H.: Die Aufmerksamkeit für, die Nutzung der und die Werbung in Medien in Deutschland, November 2010.

Nr. 69 Budzinski, Oliver: Empirische Ex-Post Evaluation von wettbewerbspolitischen Entscheidungen: Methodische Anmerkungen, Januar 2012.

Nr. 70 Budzinski, Oliver: The Institutional Framework for Doing Sports Business: Principles of EU Competition Policy in Sports Markets, January 2012.

Nr. 71 Budzinski, Oliver; Monostori, Katalin: Intellectual Property Rights and the WTO, April 2012.

Nr. 72 Budzinski, Oliver: International Antitrust Institutions, Juli 2012.

Nr. 73 Lindstädt, Nadine; Budzinski, Oliver: Newspaper vs. Online Advertising - Is There a Niche for Newspapers in Modern Advertising Markets?

Nr. 74 Budzinski, Oliver; Lindstädt, Nadine: Newspaper and Internet Display Advertising - Co-Existence or Substitution?, Juli 2012b.

Nr. 75 Budzinski, Oliver: Impact Evaluation of Merger Control Decisions, August 2012.

Nr. 76 Budzinski, Oliver; Kuchinke, Björn A.: Deal or No Deal? Consensual Arrangements as an Instrument of European Competition Policy, August 2012.

Nr. 77 Pawlowski, Tim, Budzinski, Oliver: The (Monetary) Value of Competitive Balance for Sport Consumers, Oktober 2012.

Nr. 78 Budzinski, Oliver: Würde eine unabhängige europäische Wettbewerbsbehörde eine bessere Wettbewerbspolitik machen?, November 2012.

Nr. 79 Budzinski, Oliver; Monostori, Katalin; Pannicke, Julia: Der Schutz geistiger Eigentumsrechte in der Welthandelsorganisation - Urheberrechte im TRIPS Abkommen und die digitale Herausforderung, November 2012.

Nr. 80 Beigi, Maryam H. A.; Budzinski, Oliver: On the Use of Event Studies to Evaluate Economic Policy Decisions: A Note of Caution, Dezember 2012. 
Nr. 81 Budzinski, Oliver; Beigi, Maryam H. A.: Competition Policy Agendas for Industrializing Countries, Mai 2013.

Nr. 82 Budzinski, Oliver; Müller, Anika: Finanzregulierung und internationale Wettbewerbsfähigkeit: der Fall Deutsche Bundesliga, Mai 2013.

Nr. 83 Dosse, Anna Maria: Methods for Calculating Cartel Damages: A Survey, Dezember 2013.

Nr. 84 Pawlowski, Tim; Budzinski, Oliver: Competitive Balance and Attention Level Effects: Theore-tical Considerations and Preliminary Evidence, März 2014. 